\title{
Panulirus argus virus 1 (PaV1) infection prevalence and risk factors in a Mexican lobster fishery employing casitas
}

\author{
Juan Pablo Huchin-Mian ${ }^{1, *}$, Rossanna Rodríguez-Canul ${ }^{1}$, Patricia Briones-Fourzán ${ }^{2}$, \\ Enrique Lozano-Álvarez ${ }^{2}$
}

\author{
${ }^{1}$ Laboratorio de Inmunología y Biología Molecular, Centro de Investigación y de Estudios Avanzados-Unidad Mérida, \\ Instituto Politécnico Nacional, Mérida, Yucatán 97310, Mexico \\ ${ }^{2}$ Unidad Académica de Sistemas Arrecifales, Instituto de Ciencias del Mar y Limnología, \\ Universidad Nacional Autónoma de México, Puerto Morelos, Quintana Roo 77580, Mexico
}

\begin{abstract}
In Bahía de la Ascensión in Mexico, the Caribbean spiny lobster Panulirus argus fishery is based on extensive use of artificial shelters (casitas) that can harbor both juveniles and adults of this highly gregarious species. There is concern that the use of casitas might increase contact transmission of Panulirus argus virus 1 (PaV1). However, a previous study found no evidence for lobster crowding within casitas influencing the prevalence of clinical PaV1 disease, although differences in clinical prevalence were noted between different bay environments. To investigate this more closely, 683 lobsters were sampled from casitas in 2 zones in this bay (Vigía Chico, a shallow low-vegetation zone, and Punta Allen, a deeper dense-vegetation zone) previously found to have the lowest and highest prevalence, respectively, of observed clinical signs. When hemolymph collected from these lobsters was tested by PCR, the prevalence of PaV1 infection was found to be significantly lower in Vigía Chico relative to Punta Allen irrespective of season or the size, sex, or presence of shell injuries on lobsters. Among 714 large commercial-catch lobsters collected throughout the bay, the prevalence of infection was low irrespective of year or sex. For all lobsters tested, the sensitivity (0.510) at which PaV1 infection was detected by observed clinical signs was about half that determined by PCR, but the specificity of clinical signs was absolute (1), indicating that a simple $2 \times$ correction factor can be used to accurately estimate PaV1 infection prevalence based on more easily conducted visual assessments of lobsters.
\end{abstract}

KEY WORDS: PaV1 $\cdot$ Panulirus argus $\cdot$ Commercial catch $\cdot$ Prevalence of infection $\cdot$ Artificial shelters · Sensitivity and specificity · Bahía de la Ascensión · Caribbean · Mexico

Resale or republication not permitted without written consent of the publisher

\section{INTRODUCTION}

The Caribbean spiny lobster Panulirus argus is the only known host of Panulirus argus virus 1 (PaV1) (Shields \& Behringer 2004). PaV1 has been detected in $P$. argus from numerous countries in the northwest Caribbean (Butler et al. 2008, Huchin-Mian et al. 2008, 2009, Cruz Quintana et al. 2011, Moss et al. 2013), where this species sustains important fisheries industries (Seijo 2007, Ehrhardt et al. 2010). Although PaV1 primarily impacts smaller juveniles (Shields 2011), P. argus of all sizes can become infected (Huchin-Mian et al. 2009, Behringer et al. 2012). Experimentally, PaV1 can be transmitted via ingestion of diseased tissue, water exposure over distances of a few meters, and especially by physical contact between diseased and naive lobsters (Butler et al. 2008). While some lobsters develop acute dis- 
ease resulting in mortality, many carry the infection without developing disease.

The main clinical signs of PaV1 disease are milky hemolymph that fails to clot and reddish discoloration of the exocuticule. Based on surveys for these clinical signs, the prevalence of PaV1 has been estimated to range between about 2 and $8 \%$ in Florida Keys, USA (Behringer et al. 2011), 3 and $11 \%$ in Puerto Morelos, Mexico (Lozano-Álvarez et al. 2008), 0 and $10 \%$ in Bahía de la Ascensión, Mexico (Candia-Zulbarán et al. 2012), and 0 and $9 \%$ in the Gulf of Batabanó, Cuba (Cruz Quintana et al. 2011). However, PCR testing for PaV1 has suggested that the infection prevalence might be as high as $39 \%$ at some locations in Florida, indicating that surveys based on clinical signs might grossly underestimate the prevalence of infection (Montgomery-Fullerton et al. 2007, Behringer et al. 2011). PCR testing has also been used to confirm the presence of PaV1 in asymptomatic lobsters in Cuba (Cruz Quintana et al. 2011).

Except for the smaller, early benthic juveniles ( $<20 \mathrm{~mm}$ carapace length [CL]), which tend to be asocial, Panulirus argus are socially gregarious due to chemical attraction (Ratchford \& Eggleston 1998) and express communal defense behaviors, which are exploited in some fisheries. In Florida, for example, the fishery is based on the extensive use of traps 'baited' with live sublegal lobsters that serve as attractants for larger lobsters (Behringer et al. 2012). In Cuba, the Bahamas, and some locations in Mexico, fishers deploy artificial shelters (casitas) over extensive areas as communal habitats for lobsters (Briones-Fourzán et al. 2000).

A casita is a flat slab $\left(\sim 1.5 \mathrm{~m}^{2}\right)$ supported a few centimeters above the substrate by a frame, thus creating a large artificial crevice that can shelter multiple lobsters. Since the late 1960s, casitas have been used to assist in the growth and harvesting of Panulirus argus in Bahía de la Ascensión, a large bay that sustains one of the most productive lobster fisheries in the Mexican Caribbean (Briones-Fourzán et al. 2000). In habitat-limited environments, field experiments have shown that casitas promote lobster gregariousness and survival and significantly increase lobster densities and biomass (Briones-Fourzán \& Lozano-Álvarez 2001, Briones-Fourzán et al. 2007). However, concerns remain about how the extensive use of casitas might affect the dynamics of PaV1 disease, due to infection being transmitted effectively by physical contact (Butler et al. 2008). In a recent survey of thousands of large lobsters harvested commercially over 3 yr from casitas throughout Bahía de la Ascensión, clinical signs of PaV1 were detected at only 0.7 to $1.6 \%$ prevalence (Candia-Zulbarán et al. 2012). However, when small juveniles as well as adult lobsters dwelling in casitas from 3 separate zones in the bay were examined, the prevalence of PaV1 clinical signs varied spatially and temporally from 0 to $11.6 \%$. In addition, PaV1 clinical signs were consistently less prevalent among lobsters of all sizes occupying casitas in the shallowest and least vegetated of the 3 bay zones, even though the crowding of lobsters in casitas in this zone was highest (BrionesFourzán et al. 2012).

Prevalence estimates of PaV1 infection in Panulirus argus based on observed clinical signs are likely to underestimate the real infection prevalence due to individuals with subclinical infections being missed (Behringer et al. 2012). To investigate the putative risk factors associated with PaV1 transmission among $P$. argus in fisheries reliant on casitas, the present study aimed to use PCR to accurately determine the temporal, spatial, and size-related prevalence of PaV1 infection among casita-dwelling lobsters in Bahía de la Ascensión in comparison to prevalence estimates based on observed clinical signs.

\section{MATERIALS AND METHODS}

\section{Study area}

Bahía de la Ascensión is a large $(740$ km²) shallow bay ( $3.5 \mathrm{~m}$ average depth) surrounded by coastal mangroves located within the Sian Ka'an Biosphere Reserve, Quintana Roo State, on the Caribbean coast of Mexico (Fig. 1). A series of coral banks form an interrupted reef along the mouth of the bay (LozanoÁlvarez et al. 1991). Benthic habitats comprise a complex mosaic including hard substrates, sandy areas, coral patches, and macroalgal beds interspersed among extensive seagrass meadows dominated by Thalassia testudinum and Syringodium filiforme (Briones-Fourzán et al. 2000, Vidal \& Basurto 2003).

The local fishing cooperative has divided the bay into plots called 'campos' in which fishers have exclusive rights to deploy casitas and harvest lobsters; currently, there are 101 campos and 18600 casitas in total (Sosa-Cordero et al. 2008). Most casitas are made of ferrocement slabs $\sim 1.5 \mathrm{~m}^{2}$ in area and $15 \mathrm{~cm}$ in inner height, and fishers dive to net legal-sized lobsters dwelling under them. Fishing regulations include a 4 mo closed season (1 March to 30 June), a minimum legal size of $13.5 \mathrm{~cm}$ tail length ( $74 \mathrm{~mm}$ CL; Lozano-Álvarez et al. 1991), and a prohibition on capturing egg-bearing females. 


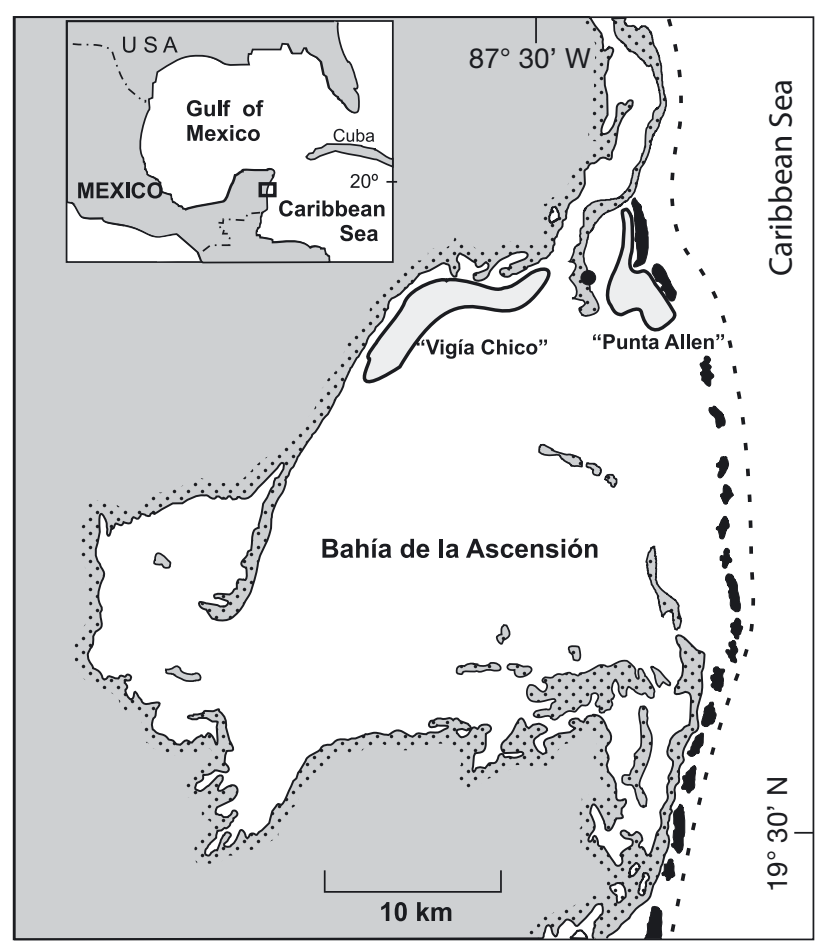

Fig. 1. Bahía de la Ascensión, with locations of the Punta Allen and Vigía Chico zones (light grey areas) where Panulirus argus were sampled directly from casitas. The series of black patches off the mouth of the bay denotes the location of the coral reef, and the broken line represents the $100 \mathrm{~m}$ depth contour. Inset: location of Bahía de la Ascensión ( $\square$ ) in Mexico

\section{Sampling from casitas}

Using hand nets, 683 Panulirus argus lobsters in total were collected from numerous casitas in multiple campos distributed across the Punta Allen and Vigía Chico zones (Fig. 1) found previously to consistently possess the highest and lowest clinical prevalence of PaV1, respectively (Briones-Fourzán et al. 2012, Candia-Zulbarán et al. 2012). Each lobster was sexed, and its CL measured using a Vernier caliper $( \pm 0.1 \mathrm{~mm})$ and examined for (1) signs of shell injuries, such as missing appendages or wound scars, which might increase susceptibility to pathogen infection (Stewart et al. 1969, Corteel et al. 2009), and (2) clinical signs of PaV1 infection as evidenced by milky white hemolymph clearly visible through the transparent membrane between the cephalothorax and the abdomen and sometimes accompanied by reddish discoloration of the exoskeleton. The tip of one pleopod was excised to score molt stage by microscopy (Lyle \& MacDonald 1983). After swabbing the exoskeleton with $70 \%$ ethanol, $300 \mu \mathrm{l}$ hemolymph was withdrawn from the base of one of the 5th pereopods using a sterile $1 \mathrm{ml}$ disposable syringe fitted with a 30 gauge needle and immediately fixed in $95 \%$ ethanol (ratio 1:3 v/v). Once fixed, hemolymph was stored in a cooler containing frozen refrigerant packs until it could be stored at $-20^{\circ} \mathrm{C}$. Following sampling, lobsters were returned to their casita. Lobsters were sampled during a cold season (November 2009 to February 2010) and a warm season (April and May 2010) to examine for seasonal variations in PaV1 infection prevalence (Behringer et al. 2011).

\section{Sampling of lobsters harvested commercially}

To determine the PaV1 infection prevalence among large Panulirus argus lobsters harvested commercially by fishers from casitas distributed widely throughout the bay, live lobsters were sampled upon fishers unloading catches at the local landing site at the beginning of 2 fishing seasons (July 2009 and July 2010), when catch numbers are typically highest (Lozano-Álvarez et al. 1991). These lobsters were sexed, measured for CL, examined for shell injuries as well as clinical signs of PaV1 infection, and moltstaged, and hemolymph was collected as for lobsters sampled directly from casitas.

\section{DNA extraction}

DNA was extracted from hemocytes using aseptic techniques to avoid sample cross-contamination. Briefly, hemolymph stored in $1.5 \mathrm{ml}$ Eppendorf tubes was thawed at ambient temperature for $15 \mathrm{~min}$ and centrifuged at $3000 \times g$ for $1 \mathrm{~min}$. The pellet containing intact hemocytes, cell debris, and clotted serum proteins ( 30 mg) was homogenized in $300 \mu \mathrm{l}$ of $10 \%$ Chelex-100 (Sigma-Aldrich) containing $20 \mu \mathrm{l}$ of $20 \mathrm{mg} \mathrm{ml}^{-1}$ Proteinase $\mathrm{K}$ by agitation for $10 \mathrm{~s}$ and incubated at $56^{\circ} \mathrm{C}$ for $3 \mathrm{~h}$ and $94^{\circ} \mathrm{C}$ for $10 \mathrm{~min}$. After being centrifuged at $3000 \times g$ for $3 \mathrm{~min}$, supernatant fluid containing DNA was carefully transferred into a sterile tube and stored at $-20^{\circ} \mathrm{C}$. DNA quality and quantity was confirmed by determining the absorbance ratio $A_{260}: A_{280}$ using a NanoDrop 2000c spectrophotometer (Thermo-Scientific), and chromosomal DNA integrity was assessed by resolving DNA in $1 \%$ agarose gels.

\section{PCR}

PaV1 DNA was amplified by PCR in a $25 \mu$ reaction containing $1 \mu \mathrm{l}$ extracted DNA, $0.33 \mu \mathrm{M}$ of each 
primer 45aF and 543aR (Montgomery-Fullerton et al. 2007), $2.5 \mathrm{mM} \mathrm{MgCl}_{2}$ (Promega), $0.6 \times$ reaction buffer (Promega), $0.4 \mathrm{mM}$ dNTP mixture (Promega), and 0.75 U Taq DNA polymerase (Promega). The thermal cycling conditions were $1 \mathrm{cycle}$ for $94^{\circ} \mathrm{C}$ for $10 \mathrm{~min}$ followed by 30 cycles of $94^{\circ} \mathrm{C}$ for $30 \mathrm{~s}, 63^{\circ} \mathrm{C}$ for $30 \mathrm{~s}$, $72^{\circ} \mathrm{C}$ for $1 \mathrm{~min}^{\circ}$ followed by $72^{\circ} \mathrm{C}$ for $10 \mathrm{~min}$. The presence of the expected $499 \mathrm{bp}$ PaV1 amplicon was determined by resolving $5 \mu \mathrm{l}$ of the PCR product and $3 \mu \mathrm{l}$ of loading buffer in a $2 \%$ agarose gel containing $0.1 \%$ ethidium bromide and DNA visualization using UV illumination (MiniBis Pro ${ }^{\circledR}$ ). Ultrapure water and hemocyte DNA extracted from lobsters heavily infected with PaV1 were used as negative and positive controls, respectively (Huchin-Mian et al. 2009).

\section{Statistical analysis}

Logistic regression was used to examine for correlations between various factors and the prevalence of PaV1 infection determined by PCR analysis. In lobsters sampled directly from casitas, the logistic model for quantifying the probability of finding lobsters infected with PaV1 included lobster size (continuous covariate), as well as zone (Punta Allen, Vigía Chico), season (warm, cold), and sex (male, female). Effects based on the presence or absence of shell injuries were tested in a separate logistic model using size as a covariate, due to injuries not being present in all lobster sample sets.

It was not possible to test whether the collection zone affected the probability of finding infected lobsters in tightly defined size classes (i.e. small juveniles, $<30 \mathrm{~mm} \mathrm{CL}$; large juveniles, 30 to $50 \mathrm{~mm} \mathrm{CL}$; subadults, $>50$ to $80 \mathrm{~mm} \mathrm{CL}$; and adults, $>80 \mathrm{~mm} \mathrm{CL}$ ) (Briones-Fourzán et al. 2012) due to the numbers of small juveniles being too low, especially at Vigía Chico, and the numbers of adult lobsters being too low at Punta Allen. However, use of the Fisher exact test showed the prevalence of infection to be similar between small and large juveniles at both Punta Allen (infected/total $=26 / 67$ and 64/186, respectively; $\mathrm{p}=$ $0.553)$ and Vigía Chico (0/18 and 3/53, respectively; $\mathrm{p}=0.566$ ), and also between subadults and adults at both Punta Allen (26/155 and 2/12, respectively; p = 1.0) and Vigía Chico (4/161 and 1/30; $\mathrm{p}=0.590$ ). Based on these data, PaV1 PCR data on small and large juveniles were pooled into a 'smaller lobster' category ( $\leq 50 \mathrm{~mm} \mathrm{CL}$ ), and PCR data on subadults and adults were pooled into a 'larger lobster' category (>50 $\mathrm{mm} \mathrm{CL}$ ) to examine for size effects (covariate) related to the probability of finding infected lobsters in each of these size categories at either collection zone.
For commercial-catch lobsters comprised exclusively of large subadults and adults, logistic regression analysis was used to assess the effects of size (covariate), year $(2009,2010)$, and sex on the probability of finding PaV1-infected lobsters. Based on the numbers of postmolt (Stage AB), intermolt (Stage C), and premolt (Stages $D_{0}$ to $D_{3-4}$ ) lobsters determined to be uninfected, subclinically infected, or clinically diseased, logistic regression analysis was also used to assess the effects of molt phase on the probability of finding PaV1-infected lobsters.

Wilson's score method with continuity correction (Newcombe 1998) was used to determine $95 \%$ confidence intervals (CI) for PaV1 infection prevalence. Statistical data was considered significant at $\mathrm{p}<0.05$, with the strength of association between any factor and PaV1 infection prevalence being presented as the odds ratio.

\section{Sensitivity and specificity of observed clinical disease}

Lobster surveys based on observed clinical disease will underestimate the prevalence of PaV1 infection due to early-stage subclinical infections being missed. However, it remains unknown to what extent clinical prevalence will be underestimated compared to infection prevalence determined by PCR (Lalkhen $\&$ McCluskey 2008). To determine this as precisely as possible for the lobster population inhabiting Bahía de la Ascensión, data on lobsters collected from casitas and assessed from the commercial catch were combined to increase the sample size and to include lobsters of all sizes (Cameron 2002). For these lobsters, we assessed the utility of observed clinical signs to determine PaV1 infection prevalence relative to PCR (sensitivity = number of lobsters with clinical signs divided by total number of PCR-positive lobsters) and to correctly identify uninfected lobsters relative to PCR (specificity = number of lobsters without clinical signs divided by total number of PCRnegative lobsters).

\section{RESULTS}

\section{Prevalence of PaV1 infection in casita-dwelling lobsters}

The prevalence of PaV1 infection was determined by either observed clinical signs or PCR for a total of 683 lobsters varying in CL from 12.8 to $115.2 \mathrm{~mm}$ and 
Table 1. Panulirus argus. Numbers of lobsters sampled from casitas by PCR tests, and clinical signs of Panulirus argus virus 1 (PaV1) infection. CL: carapace length (smaller lobsters, $\leq 50 \mathrm{~mm} \mathrm{CL;} \mathrm{larger} \mathrm{lobsters,} \mathrm{>50} \mathrm{mm} \mathrm{CL)}$

\begin{tabular}{|c|c|c|c|c|c|c|}
\hline Category & $\begin{array}{c}\text { PCR- } \\
\text { No clinical } \\
\text { signs }\end{array}$ & $\begin{array}{c}\overline{\text { Clinical }} \\
\text { signs }\end{array}$ & $\begin{array}{c}\text { PCR+ } \\
\text { Sub-clinical } \\
\text { infection }\end{array}$ & $\begin{array}{c}\text { Total } \\
\text { infected }\end{array}$ & $\begin{array}{c}\text { Total } \\
\text { lobsters }\end{array}$ & $\begin{array}{c}\text { PaV1 prev. (\%) } \\
\quad(95 \% \mathrm{CI})\end{array}$ \\
\hline \multicolumn{7}{|l|}{ Zone } \\
\hline Punta Allen & 302 & 63 & 55 & 118 & 420 & $28.1(23.9-32.7)$ \\
\hline Vigía Chico & 255 & 2 & 6 & 8 & 263 & $3.0(1.3-6.3)$ \\
\hline \multicolumn{7}{|l|}{ Season } \\
\hline Warm & 303 & 29 & 30 & 59 & 362 & $16.3(12.7-20.6)$ \\
\hline Cold & 254 & 36 & 31 & 67 & 321 & $20.9(16.6-25.8)$ \\
\hline \multicolumn{7}{|l|}{ Sex } \\
\hline Female & 250 & 37 & 31 & 68 & 318 & $21.4(17.1-26.4)$ \\
\hline Male & 307 & 28 & 30 & 58 & 365 & $15.9(12.4-20.1)$ \\
\hline \multicolumn{7}{|l|}{ Shell injuries } \\
\hline No & 454 & 47 & 48 & 95 & 549 & $17.3(14.3-20.1)$ \\
\hline Yes & 103 & 18 & 13 & 31 & 134 & $23.1(16.5-31.4)$ \\
\hline \multicolumn{7}{|l|}{ Size class } \\
\hline Smaller & 231 & 55 & 38 & 93 & 324 & $28.7(23.9-34.0)$ \\
\hline Larger & 326 & 10 & 23 & 33 & 359 & $9.2(6.5-12.8)$ \\
\hline Total sample & 557 & 65 & 61 & 126 & 683 & $18.4(15.6-21.6)$ \\
\hline
\end{tabular}

collected from casitas at 2 zones (420 at Punta Allen, 263 at Vigía Chico) within Bahía de la Ascensión (Table 1). While $28 \%$ of the lobsters collected at Punta Allen tested PCR-positive for PaV1, only $3 \%$ of lobsters collected at Vigía Chico were PCR-positive. All lobsters exhibiting clinical signs tested PCR-positive for PaV1, and as expected, some lobsters without clinical signs also tested PCRpositive for PaV1. Logistic regression analyses showed that the probability of finding infected lobsters decreased as lobster size increased, and was not affected significantly by lobster sex, lobsters possessing shell injuries, or season, but was significantly lower among lobsters from Vigía Chico than from Punta Allen ( $p<0.0001$, odds ratio: 0.31) (Table 2).

The mean size of lobsters (Student's $t$-test, $t=$ 8.601, $\mathrm{df}=681, \mathrm{p}<0.0001)$ and size of PaV1-infected lobsters $(t=3.672, \mathrm{df}=124, \mathrm{p}=0.0004)$ was significantly greater for those collected at Vigía Chico (mean \pm SD for all lobsters: $59.3 \pm 17.8 \mathrm{~mm} \mathrm{CL}$ and infected lobsters: $62.2 \pm 18.8 \mathrm{~mm} \mathrm{CL}$ ) than at Punta Allen (mean \pm SD for all lobsters: $47.4 \pm 17.6 \mathrm{~mm} \mathrm{CL}$ and infected lobsters: $41.1 \pm 15.5 \mathrm{~mm} \mathrm{CL})$. Logistic regression analyses for smaller ( $\leq 50 \mathrm{~mm} \mathrm{CL}$ ) and larger (>50 mm CL) lobsters showed that within each of these size categories, the probability of finding infected lobsters was not affected by size but was significantly lower in Vigía Chico relative to Punta Allen (odds ratios: 0.28 and 0.37 for smaller and larger lobsters, respectively) (Table 3). Thus, 35.6\% of smaller lobsters and $16.8 \%$ of larger lobsters collected at Punta Allen tested PCR-positive for PaV1 compared to only $4.2 \%$ and $2.6 \%$ of smaller and larger lobsters, respectively, collected at Vigía Chico (Fig. 2).

\section{Prevalence of PaV1 infection in commercial-catch lobsters}

In total, 714 lobsters (309 in 2009, 405 in 2010) ranging in size from 71 to $168 \mathrm{~mm}$ CL were sampled 
from the commercial catch at Bahía de la Ascensión. Although the mean size of lobsters varied between 2009 (mean \pm SD, $86.4 \pm 10.8 \mathrm{~mm} \mathrm{CL}$ ) and 2010 $(84.5 \pm 10.5 \mathrm{~mm} \mathrm{CL})$ (Student's $t$-test, $t=2.370, \mathrm{df}=$ $712, \mathrm{p}=0.018)$, the percentage of subadults was similar in 2009 (32.7\%) and 2010 (37.7\%, $2 \times 2$ contingency table analysis, Yates-corrected $\chi^{2}{ }_{1}=1.77, \mathrm{p}=$ 0.184) (Table 4). Of all commercial lobsters sampled in 2009 and 2010, only 6 (1.9\%) and 4 (1.0\%), respectively, exhibited clinical signs of PaV1, with 14 $(4.5 \%)$ and $7(1.7 \%)$, respectively, including all those displaying clinical signs, testing PCR-positive for PaV1 (Table 4). Even though numbers of PaV1-infected lobsters were low, logistic regression analyses indicated that the probability of finding PaV1infected lobsters in the commercial catch decreased as lobster size increased, but did not vary with sex or year (Table 5). Logistic regression analyses also indicated that the probability of finding infected lobsters was significantly higher among subadults than

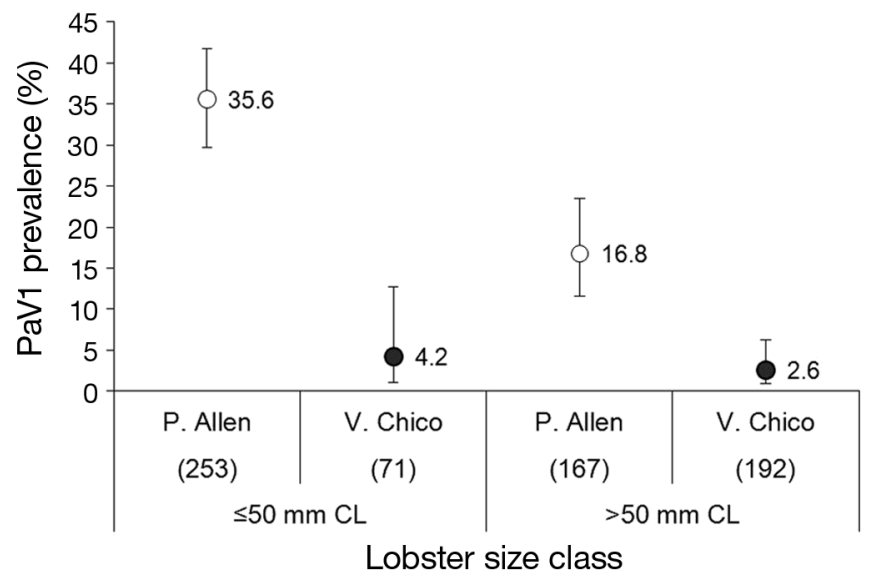

Fig. 2. Panulirus argus. PCR prevalence of Panulirus argus virus $1(\mathrm{PaV} 1)$ infection among smaller $(\leq 50 \mathrm{~mm}$ carapace length [CL]) and larger (>50 mm CL) lobsters sampled from casitas in Punta Allen (P. Allen) and Vigía Chico (V. Chico). Numbers in parentheses are sample sizes, and error bars denote $95 \%$ CI among adults $(\mathrm{p}=0.017$, odds ratio: 1.65$)$ (Table 5).

\section{PaV1 infection and molt stage}

Molt stage was determined for $641(94 \%)$ of the 683 lobsters sampled from casitas and 704 (96\%) of the 714 lobsters sampled from the commercial catch. Overall, most lobsters were in intermolt, but the proportions varied between casitas and commercial-catch lobsters and relative to PaV1 infection (Table 6). In lobsters sampled from

Table 3. Panulirus argus. Logistic regression analyses testing the effect of various factors on the probability of finding Panulirus argus virus 1 (PaV1)-infected lobsters within 2 broad size classes in casitas. Smaller lobsters: $\leq 50 \mathrm{~mm}$ carapace length (CL); range: 12.8-50.0 $\mathrm{mm} \mathrm{CL}$. Larger lobsters: >50 $\mathrm{mm} \mathrm{CL}$; range: 50.1-115.0 mm CL. For both size categories, factors were size (covariate) and zone

(Vigía Chico, Punta Allen). Reference level was 'Punta Allen'

\begin{tabular}{|lcrrrrr|}
\hline Effect & Estimate & SE & $\begin{array}{c}\text { Wald } \\
\text { statistic }\end{array}$ & df & $p$ & \multicolumn{1}{c|}{$\begin{array}{c}\text { Odds ratio } \\
(95 \% \text { CI })\end{array}$} \\
\hline Smaller lobsters & & & & & & \\
Size & -0.012 & 0.014 & 0.718 & 1 & 0.397 & $0.99(0.96-1.02)$ \\
Zone: Vigía Chico & -1.266 & 0.302 & 17.543 & 1 & $<0.001$ & $0.28(0.16-0.51)$ \\
Larger lobsters & & & & & & \\
Size & -0.020 & 0.019 & 1.109 & 1 & 0.292 & $0.98(0.94-1.02)$ \\
Zone: Vigía Chico & -0.984 & 0.250 & 15.440 & 1 & $<0.001$ & $0.37(0.23-0.61)$ \\
\hline
\end{tabular}

Table 4. Panulirus argus. Numbers of lobsters sampled from the commercial catch by PCR tests and clinical signs for Panulirus argus virus 1 (PaV1) infection

\begin{tabular}{|c|c|c|c|c|c|c|}
\hline Category & $\begin{array}{c}\text { PCR- } \\
\text { No clinical } \\
\text { signs }\end{array}$ & $\begin{array}{c}\overline{\text { Clinical }} \\
\text { signs }\end{array}$ & $\begin{array}{c}\mathrm{PCR}+ \\
\text { Sub-clinical } \\
\text { infection }\end{array}$ & $\begin{array}{c}\text { Total } \\
\text { infected }\end{array}$ & $\begin{array}{c}\text { Total } \\
\text { lobsters }\end{array}$ & $\begin{array}{c}\text { PaV1 prev. }(\%) \\
\quad(95 \% \mathrm{CI})\end{array}$ \\
\hline \multicolumn{7}{|l|}{ Year } \\
\hline 2009 & 295 & 6 & 8 & 14 & 309 & $4.5(2.6-7.7)$ \\
\hline 2010 & 398 & 4 & 3 & 7 & 405 & $1.7(0.8-3.7)$ \\
\hline \multicolumn{7}{|l|}{ Sex } \\
\hline Female & 310 & 5 & 5 & 10 & 320 & $3.1(1.6-5.8)$ \\
\hline Male & 383 & 5 & 6 & 11 & 394 & $2.8(1.5-5.1)$ \\
\hline \multicolumn{7}{|c|}{ Ontogenetic phase } \\
\hline Subadult & 245 & 4 & 5 & 9 & 254 & $3.5(1.7-6.8)$ \\
\hline Adult & 448 & 6 & 6 & 12 & 460 & $2.6(1.4-4.6)$ \\
\hline Total sample & 693 & 10 & 11 & 21 & 714 & $2.9(1.9-4.5)$ \\
\hline
\end{tabular}


Table 5. Panulirus argus. Logistic regression analyses testing the effects of various factors on the probability of finding Panulirus argus virus 1 (PaV1)-infected lobsters in the commercial catch. Model A factors were size (covariate), year (2009, 2010), and sex (female, male); reference levels were '2010' and 'male'. Model B factors were year $(2009,2010)$ and ontogenetic phase (subadult, adult); reference levels were '2010' and 'adult'

\begin{tabular}{|lrcccccc|}
\hline Effect & Estimate & SE & $\begin{array}{c}\text { Wald } \\
\text { statistic }\end{array}$ & df & $p$ & $\begin{array}{c}\text { Odds ratio } \\
(95 \% \text { CI })\end{array}$ \\
\hline Model A & & & & & & \\
Size & -0.059 & 0.026 & 5.304 & 1 & 0.021 & $0.94(0.90-0.99)$ \\
Year: 2009 & 0.364 & 0.189 & 3.714 & 1 & 0.054 & $1.44(0.99-2.08)$ \\
Sex: female & -0.075 & 0.195 & 0.149 & 1 & 0.700 & $0.93(0.63-1.36)$ \\
Model B & & & & & & \\
$\quad$ Year: 2009 & 0.402 & 0.208 & 3.722 & 1 & 0.054 & $1.49(0.99-2.25)$ \\
Ontogenic phase: & 0.499 & 0.208 & 5.738 & 1 & 0.017 & $1.65(1.09-2.48)$ \\
$\quad$ subadult & & & & & & & \\
\hline
\end{tabular}

CI: 0.427 to 0.593$)$. No clinical signs were evident in any of 1250 lobsters that tested PCR-negative for PaV1 (clinical-signs specificity: $1250 / 1250=1 ; 95 \%$ CI: 0.996 to 1.0).

\section{DISCUSSION}

Of the potential risk factors of PaV1 infection considered for Panulirus argus sampled directly from casitas (lobster size, sex, and presence of shell injuries, as well as season and zones in Bahía de la Ascensión), only size and zone

casitas, all those displaying clinical signs were in intermolt, while others with subclinical PaV1 infections detected by PCR occurred among postmolt, intermolt, and premolt individuals, with no significant difference in the proportions of infected individuals in the 3 molt phases $\left(2 \times 3\right.$ contingency table, $\chi_{2}^{2}$ $=3.263, \mathrm{p}=0.196)$. All PCR-positive lobsters in the commercial catch were in intermolt (Table 6). Logistic regression analyses showed that relative to lobsters in premolt, the probability of finding infected lobsters did not differ significantly in lobsters in postmolt, but was significantly higher for lobsters in intermolt (odds ratio: 5.6) (Table 7).

\section{Sensitivity and specificity of observed clinical signs relative to PCR detection of PaV1}

Of the 1397 lobsters examined in total (size range: 12.8 to $168.0 \mathrm{~mm} \mathrm{CL}$ ), clinical signs were evident in 75 of the 147 lobsters that tested PCR-positive for PaV1 (clinical-signs sensitivity: 75/147 $=0.510 ; 95 \%$ affected the probability of finding PCR-positive lobsters. A lower PaV1 infection prevalence among larger lobsters is well established, and a recent study (Candia-Zulbarán et al. 2012) also found that the prevalence of PaV1 clinical signs was higher among lobsters at Punta Allen (8.4\%, $\mathrm{n}=1842)$ compared to Vigía Chico $(1.5 \%, n=2016)$. However, in the present study, the use of PCR detected PaV1 infection at much higher prevalence at both the Punta Allen (28.1\% of 420 lobsters) and the Vigía Chico (3.0\% of 263 lobsters) zones compared with prevalence of clinical signs (15\% and $0.8 \%$, respectively). These prevalence differences were not due to differences in the size of lobsters sampled at the 2 zones, as the infection prevalence among both smaller $(\leq 50 \mathrm{~mm}$ CL) and larger individuals (>50 mm CL) was significantly lower at Vigía Chico than at Punta Allen, suggesting potential involvement of local environmental factors not normalized by the use of casitas (BrionesFourzán et al. 2012).

Disease outbreaks caused by some crustacean pathogens have been associated with distinct physio-

Table 6. Panulirus argus. Percentages of lobsters in different molt stages that were collected from casitas (size range: 12.8-115.2 mm carapace length [CL]) and from the commercial catch (size range: $70.8-168.0 \mathrm{~mm} \mathrm{CL}$ )

\begin{tabular}{|c|c|c|c|c|c|c|c|c|c|}
\hline \multirow[t]{2}{*}{ Infection status } & \multirow{2}{*}{$\begin{array}{l}\text { No. of } \\
\text { lobsters }\end{array}$} & \multirow{2}{*}{$\begin{array}{c}\text { Postmolt } \\
\text { AB }\end{array}$} & \multirow{2}{*}{$\begin{array}{c}\text { Intermolt } \\
\mathrm{C}\end{array}$} & \multicolumn{6}{|c|}{ _ Premolt } \\
\hline & & & & $\mathrm{D}_{0}$ & $\mathrm{D}_{1}^{\prime}$ & $\mathrm{D}_{1}^{\prime \prime}$ & $\mathrm{D}_{1}^{\prime \prime \prime}$ & $\mathrm{D}_{2}$ & $\mathrm{D}_{3-4}$ \\
\hline Casitas & 641 & & & & & & & & \\
\hline No infection & 529 & 6.0 & 76.0 & 0.9 & 3.6 & 3.3 & 2.6 & 4.3 & 3.3 \\
\hline Subclinical infection & 57 & 5.3 & 86.0 & 0 & 5.3 & 0 & 0 & 0 & 3.4 \\
\hline Clinical signs of infection & 55 & 0 & 100 & 0 & 0 & 0 & 0 & 0 & 0 \\
\hline Commercial catch & 704 & & & & & & & & \\
\hline No infection & 683 & 3.1 & 84.8 & 1.6 & 4.3 & 1.6 & 1.5 & 1.6 & 1.6 \\
\hline Subclinical infection & 11 & 0 & 100 & 0 & 0 & 0 & 0 & 0 & 0 \\
\hline Clinical signs of infection & 10 & 0 & 100 & 0 & 0 & 0 & 0 & 0 & 0 \\
\hline
\end{tabular}


Table 7. Panulirus argus. Logistic regression analysis testing the effects of size and molt phase on the probability of finding lobsters infected with Panulirus argus virus 1 (PaV1). Molt phases were postmolt, intermolt, and premolt; reference level was 'premolt'. Samples from casitas and the commercial catch were combined (size range: $12.8-168.0 \mathrm{~mm}$ carapace length)

\begin{tabular}{|c|c|c|c|c|c|c|}
\hline Effect & Estimate & SE & $\begin{array}{c}\text { Wald } \\
\text { statistic }\end{array}$ & df & $\mathrm{p}$ & $\begin{array}{l}\text { Odds ratio } \\
(95 \% \text { CI })\end{array}$ \\
\hline Size & -0.047 & 0.005 & 107.869 & 1 & $<0.001$ & $0.95(0.94-0.96)$ \\
\hline Molt phase: intermolt & t 1.726 & 0.474 & 13.281 & 1 & $<0.001$ & $5.62(2.22-14.22)$ \\
\hline Molt phase: postmolt & 0.589 & 0.769 & 0.587 & 1 & 0.443 & $1.80(0.39-8.13)$ \\
\hline
\end{tabular}

graphic and hydrographic stressors. For example, some natural systems like fjords or shallow, poorly drained bays and lagoons have been demonstrated to favor the spread of crustacean pathogens through assisting in infection transmission or retention of the viable pathogen within the system (see reviews in Stentiford \& Shields 2005, Shields 2012). Habitat comparisons of zones within Bahía de la Ascensión including Vigía Chico and Punta Allen have identified the former to be shallower and more sparsely vegetated; thus, it was hypothesized that PaV1 might be transmitted less effectively in shallow habitats due to virus inactivation from increased exposure to solar UV radiation (Briones-Fourzán et al. 2012). Supporting data obtained here on a much higher PaV1 infection prevalence at Punta Allen underlines the need to specifically investigate the possibility that dense habitats protecting lobsters and virus from solar UV radiation elevates the risk of PaV1 transmission. This is important because marine vegetation constitutes the settlement habitat for Panulirus argus, and $\mathrm{PaV} 1$ has been detected by PCR in recently settled postlarvae (Moss et al. 2012).

Effects of shell injuries and molt stage on PaV1 infection prevalence were investigated, as these might provide opportunities for enhanced pathogen entry, as found, for example, with Aerococcus viridans in the clawed lobster Homarus americanus, where infection is often transmitted through integument ruptures (Stewart et al. 1969), and with white spot syndrome virus (WSSV) in penaeid shrimp, where infection is transmitted via water more easily to shrimp in postmolt rather than premolt stages, and especially in shrimp with shell wounds (Corteel et al. 2009). Despite this, no evidence was found for the existence of shell wounds in Panulirus argus elevating the probability of PaV1 infection, although this needs to be confirmed experimentally under controlled conditions.

As most lobsters examined were in intermolt, the probability of finding PaV1 infection in these lobsters was significantly higher than in premolt- or postmolt-stage lobsters. Despite this finding and the small numbers of premolt and postmolt lobsters examined, this might not necessarily implicate differences in infection risk, particularly as when PaV1 infection becomes more severe, lobsters undergo metabolic changes that suppress molting (Li et al. 2008, Pascual Jiménez et al. 2012). Consistent with this, the carapace of many of the Panulirus argus displaying PaV1 clinical signs was heavily fouled, indicative of their intermolt being prolonged (Briones-Fourzán \& Lozano-Álvarez 2003). The fact that all lobsters found to have subclinical PaV1 infections and sampled from the commercial catch, but not from casitas, were also in intermolt may simply reflect the decrease in molt frequency that occurs with increasing lobster age.

Juveniles of many crustacean species are more susceptible to infection by viruses, including PaV1, potentially due to their elevated sensitivity to environmental stressors (see reviews in Behringer et al. 2011, Shields 2012) and/or to physiological stressors induced, for example, by more frequent molting (Messick \& Shields 2000). In addition, it has been hypothesized that marine vegetation might serve as a reservoir for viruses and shade them against solar UV inactivation (Briones-Fourzán et al. 2012). This might explain at least in part why smaller juvenile Panulirus argus that are typically asocial, dwell among the vegetation, and molt more frequently, typically exhibit the highest prevalence of PaV1 infection.

Molecular diagnostic tests based on fluorescence in situ hybridization (FISH) and PCR have proved to be useful in detecting subclinical viral infections in many crustaceans, including penaeid shrimp (Peinado-Guevara \& López-Meyer 2006). With WSSV in penaeid shrimp, for example, clinical signs develop between 1 to 3 d post-infection, but viral DNA can be detected by PCR as early as $6 \mathrm{~h}$ post-infection (Lightner 1996, Chou et al. 1998). Until relatively recently, the only means of detecting PaV1 without sampling Panulirus argus sacrificially for histology was to visually examine them for gross clinical signs of disease (Shields \& Behringer 2004, Lozano-Álvarez et al. 2008, Cruz Quintana et al. 2011). The availability of a PCR test for PaV1 is thus valuable, particularly as clinical signs do not develop in $P$. argus juveniles until 6 wk post-infection with PaV1, and as adults that might act as reservoirs rarely develop symptoms 
of disease (Behringer et al. 2006, 2012). Using a 1-step PCR for PaV1 (Montgomery-Fullerton et al. 2007), asymptomatic PaV1 infection was detected in the present study in 72 of the 1397 lobsters examined that ranged in size from 14.5 to $96.0 \mathrm{~mm} \mathrm{CL}$, and in all 75 lobsters displaying clinical signs of PaV1 disease. The ability of PCR to detect PaV1 infection in commercially harvested lobsters in the absence of pathology has important trade implications, as such asymptomatic live lobsters might increase the risk of translocating the virus to naive populations of Caribbean spiny lobsters (Huchin-Mian et al. 2009), as has occurred for example with WSSV in penaeid shrimp (Hasson et al. 2006).

Routine surveillance for viral infections among wild crustacean populations using PCR is timeconsuming and costly, particularly when the infection prevalence is relatively low, as found with PaV1 among adult lobsters in Bahía de la Ascensión and among all lobsters in the Vigía Chico zone of this bay, and when hemolymph, for example, needs to be collected as a source of DNA. In contrast, visually assessing lobsters for PaV1 clinical disease is quick and easy and found in the present study to be as specific for infection detection as PCR. However, its sensitivity of infection detection was found to be only about half (0.51) that of PCR by missing those lobsters with subclinical infections. However, as diagnostic sensitivity and specificity are independent of prevalence (Lalkhen \& McCluskey 2008), in cases where high number of lobsters of various sizes are examined, underestimates in PaV1 infection prevalence based on observed clinical signs might be corrected quite accurately and simply by applying a $2 \times$ correction factor (Pestal et al. 2003).

Diseases adversely impact many populations of crustaceans exploited commercially (Shields 2012), and fishing practices can exacerbate disease dynamics. For example, the prevalence of PaV1 infection in lobsters sampled from commercial lobster traps deployed over a wide area of the Florida fishery was $11 \%$, suggesting that trap confinement for several days might increase the potential for transmission of PaV1 through direct contact, cannibalism due to lack of food, and/or confinement-induced stress, which may increase lobster susceptibility to PaV1 (Behringer et al. 2012). Among these options, as contact was advocated as the most likely mechanism of PaV1 transmission, fisheries not reliant on artificial habitat structures that concentrate lobsters have been advocated to lower the risk of PaV1 infection (Behringer et al. 2012). Despite this assertion, the prevalence of PaV1 detected by PCR in the casita-based fishery of
Bahía de la Ascensión was lower in both 2009 (4.5\%, $\mathrm{n}=309)$ and $2010(1.7 \%, \mathrm{n}=405)$ than that detected $(11 \%, \mathrm{n}=502)$ in the Florida trap fishery (Behringer et al. 2012). In the Bahamas, where casitas are also used extensively, legal-size lobsters also exhibit a low prevalence of PaV1 infection as detected by PCR $(0.5 \%, n=788)$ (Moss et al. 2013). Indeed, it has been contested that casitas might actually reduce the potential for contact transmission, due to the large shelter area $\left(1.5 \mathrm{~m}^{2}\right)$ allowing naive lobsters to cohabit with diseased lobsters with little if any physical contact (Lozano-Álvarez et al. 2008). It might also be possible that naive lobsters abandon a casita to avoid diseased individuals. Moreover, confinementinduced stress will rarely be an issue with casitas, as lobsters can move freely between nearby casitas and natural shelters, thus increasing their foraging range and reducing the potential for cannibalism (BrionesFourzán et al. 2007). The effects of commercial Panulirus argus harvesting on the dynamics of PaV1 infection and disease remain, however, a complex issue that needs both field and laboratory studies incorporating investigations of different host populations, PaV1 strains (Moss et al. 2012, 2013), environmental features, and fishing practices.

\begin{abstract}
Acknowledgements. We thank Fernando Negrete-Soto and Cecilia Barradas-Ortiz for their invaluable technical support, Rebeca Candia-Zulbarán and Álvar Fuentes-Breña for their help with sampling lobsters, and members of the Sociedad Cooperativa 'Pescadores de Vigía Chico' for providing logistical support and access to their fishing campos. Funding from the Universidad Nacional Autónoma de México, Consejo Nacional de Ciencia y Tecnología (México) (Project No. 82724-Q and Doctoral Studentship No. 166083 for J.P.H.M.), and external services from the Laboratory of Immunology and Molecular Biology of CINVESTAV-IPN, Unidad Mérida (Ref. No. 10603) are appreciated. Annual permits to sample lobsters from Bahía de la Ascensión were issued by the Comisión Nacional de Acuacultura y Pesca, México.
\end{abstract}

\section{LITERATURE CITED}

Behringer DC, Butler MJ IV, Shields JD (2006) Avoidance of disease in social lobsters. Nature 441:421

Behringer DC, Butler MJ IV, Shields JD, Moss J (2011) Review of Panulirus argus virus 1 - a decade after its discovery. Dis Aquat Org 94:153-160

Behringer DC, Butler MJ IV, Moss J, Shields JD (2012) PaV1 infection in the Florida spiny lobster (Panulirus argus) fishery and its effects on trap function and disease transmission. Can J Fish Aquat Sci 69:136-144

> Briones-Fourzán P, Lozano-Álvarez E (2001) Effects of artificial shelters (Casitas) on the abundance and biomass of juvenile spiny lobsters Panulirus argus in a habitatlimited tropical reef lagoon. Mar Ecol Prog Ser 221: 221-232 
Briones-Fourzán P, Lozano-Álvarez E (2003) Factors affecting growth of the spiny lobsters Panulirus gracilis and Panulirus inflatus (Decapoda: Palinuridae) in Guerrero, Mexico. Rev Biol Trop 51:165-174

Briones-Fourzán P, Lozano-Álvarez E, Eggleston DB (2000) The use of artificial shelters (Casitas) in research and harvesting of Caribbean spiny lobsters in Mexico. In: Phillips BF, Kittaka J (eds) Spiny lobsters: fisheries and culture, 2nd edn. Blackwell, Oxford, p 420-446

> Briones-Fourzán P, Lozano-Álvarez E, Negrete-Soto F, Barradas-Ortiz C (2007) Enhancement of juvenile Caribbean spiny lobsters: an evaluation of changes in multiple response variables with the addition of large artificial shelters. Oecologia 151:401-416

> Briones-Fourzán P, Candia-Zulbarán RI, Negrete-Soto F, Barradas-Ortiz C, Huchin-Mian JP, Lozano-Álvarez E (2012) Influence of local habitat features on disease avoidance by Caribbean spiny lobsters in a casitaenhanced bay. Dis Aquat Org 100:135-148

$>$ Butler MJ, Behringer DC, Shields JD (2008) Transmission of Panulirus argus virus 1 (PaV1) and its effect on the survival of juvenile Caribbean spiny lobster. Dis Aquat Org 79:173-182

Cameron A (2002) Survey toolbox for aquatic animal diseases. Monograph No. 94. Australian Centre for International Agriculture Research (ACIAR), Canberra

> Candia-Zulbarán RI, Briones-Fourzán P, Negrete-Soto F, Barradas-Ortiz C, Lozano-Álvarez E (2012) Variability in clinical prevalence of PaV1 in Caribbean spiny lobsters occupying commercial casitas over a large bay in Mexico. Dis Aquat Org 100:125-133

> Chou HY, Huang CY, Lo CF, Kou GH (1998) Studies on transmission of white spot syndrome associated baculovirus (WSBV) in Penaeus monodon and P. japonicus via waterborne contact and oral ingestion. Aquaculture 164: 263-276

> Corteel M, Dantas-Lima JJ, Wille M, Alday-Sanz V, Pensaert MB, Sorgeloos P, Nauwynck HJ (2009) Molt stage and cuticle damage influence white spot syndrome virus immersion infection in penaeid shrimp. Vet Microbiol 137:209-216

Cruz Quintana Y, Rodríguez Canul R, Vidal Martínez VM (2011) First evidence of Panulirus argus Virus 1 (PaV1) in spiny lobster from Cuba and clinical estimation of its prevalence. Dis Aquat Org 93:141-147

Ehrhardt NM, Puga R, Butler MJ IV (2010) Implications of the ecosystem approach to fisheries management in large ecosystems: the case of the Caribbean spiny lobster. In: Fanning L, Mahon R, McConney P (eds) Towards marine ecosystem-based management in the wider Caribbean. Amsterdam University Press, Amsterdam, p 157-175

> Hasson KW, Fan Y, Reisinger T, Venuti J, Varner PW (2006) White-spot syndrome virus (WSSV) introduction into the Gulf of Mexico and Texas freshwater systems through imported, frozen bait-shrimp. Dis Aquat Org 71: 91-100

> Huchin-Mian JP, Rodríguez-Canul R, Arias-Bañuelos E, Simá-Álvarez R, Pérez-Vega JA, Briones-Fourzán P, Lozano-Álvarez E (2008) Presence of Panulirus argus Virus 1 (PaV1) in juvenile spiny lobsters Panulirus argus from the Caribbean coast of Mexico. Dis Aquat Org 79: 153-156

Huchin-Mian JP, Briones-Fourzán P, Simá-Álvarez R, CruzQuintana Y and others (2009) Detection of Panulirus argus Virus 1 (PaV1) in exported frozen tails of subadult-adult Caribbean spiny lobsters Panulirus argus. Dis Aquat Org 86:159-162

- Lalkhen AG, McCluskey A (2008) Clinical tests: sensitivity and specificity. Contin Educ Anaesth Crit Care Pain 8: 221-223

> Li C, Shields JD, Ratzlaff RE, Butler MJ (2008) Pathology and hematology of the Caribbean spiny lobster experimentally infected with Panulirus argus virus 1 (PaV1). Virus Res 132:104-113

Lightner DV (1996) A handbook of shrimp pathology and diagnostic procedures for diseases of cultured penaeid shrimp. World Aquaculture Society, Baton Rouge, LA

Lozano-Álvarez E, Briones-Fourzán P, Phillips BF (1991) Fishery characteristics, growth and movements of the spiny lobster Panulirus argus in Bahía de la Ascensión, Mexico. Fish Bull 89:79-89

> Lozano-Álvarez E, Briones-Fourzán P, Ramírez-Estévez A, Placencia-Sánchez D, Huchin-Mian JP, Rodríguez-Canul R (2008) Prevalence of Panulirus argus Virus 1 (PaV1) and habitation patterns of healthy and diseased Caribbean spiny lobsters in shelter-limited habitats. Dis Aquat Org 80:95-104

Lyle W, MacDonald C (1983) Molt stage determination in the Hawaiian spiny lobster Panulirus marginatus. J Crustac Biol 3:208-216

Messick GA, Shields JD (2000) Epizootiology of the parasitic dinoflagellate Hematodinium sp. in the American blue crab Callinectes sapidus. Dis Aquat Org 43: $139-152$

Montgomery-Fullerton MM, Cooper RA, Kauffman KM, Shields JD, Ratzlaff RE (2007) Detection of Panulirus argus Virus 1 in Caribbean spiny lobsters. Dis Aquat Org 76:1-6

> Moss J, Butler MJ IV, Behringer DC, Shields JD (2012) Genetic diversity of the Caribbean spiny lobster virus, Panulirus argus virus 1 (PaV1), and the discovery of PaV1 in lobster postlarvae. Aquat Biol 14:223-232

- Moss J, Behringer D, Shields JD, Baeza A and others (2013) Distribution, prevalence, and genetic analysis of Panulirus argus virus 1 (PaV1) from the Caribbean Sea. Dis Aquat Org 104:129-140

> Newcombe RG (1998) Two-sided confidence intervals for the single proportion: comparison of seven methods. Stat Med 17:857-872

> Pascual Jiménez C, Huchin-Mian JP, Simões N, BrionesFourzán P and others (2012) Physiological and immunological characterization of Caribbean spiny lobsters Panulirus argus naturally infected with Panulirus argus Virus 1 (PaV1). Dis Aquat Org 100:113-124

> Peinado-Guevara LI, López-Meyer M (2006) Detailed monitoring of white spot syndrome virus (WSSV) in shrimp commercial ponds in Sinaloa, Mexico, by nested PCR. Aquaculture 251:33-45

- Pestal GP, Taylor DM, Hoenig JM, Shields JD, Pickavance R (2003) Monitoring the prevalence of the parasitic dinoflagellate Hematodinium sp. in snow crabs Chionoecetes opilio from Conception Bay, Newfoundland. Dis Aquat Org 53:67-75

> Ratchford SG, Eggleston DB (1998) Size- and scale-dependent chemical attraction contribute to an ontogenetic shift in sociality. Anim Behav 56:1027-1034

> Seijo JC (2007) Considerations for management of metapopulations in small-scale fisheries of the Mesoamerican barrier reef ecosystem. Fish Res 87:86-91 
Shields JD (2011) Diseases of spiny lobsters: a review. J Invertebr Pathol 106:79-91

Shields JD (2012) The impact of pathogens on exploited populations of decapod crustaceans. J Invertebr Pathol 110:211-224

Shields JD, Behringer DC Jr (2004) A new pathogenic virus in the Caribbean spiny lobster Panulirus argus from the Florida Keys. Dis Aquat Org 59:109-118

Sosa-Cordero E, Liceaga-Correa MLA, Seijo JC (2008) The Punta Allen lobster fishery: current status and recent trends. In: Townsed R, Uchida H (eds) Case studies in fisheries self-governance. FAO Fish Tech Pap 504. FAO,

Editorial responsibility: Jeff Cowley,

Brisbane, Queensland, Australia
Rome, p 149-162

Stentiford GD, Shields JD (2005) A review of the parasitic dinoflagellates Hematodinium species and Hematodinium-like infections in marine crustaceans. Dis Aquat Org 66:47-70

Stewart JE, Dockrill A, Cornick JW (1969) Effectiveness of the integument and gastric fluid as barriers against transmission of Gaffkya homari to the lobster Homarus americanus. J Fish Res Board Can 26:1-14

Vidal L, Basurto M (2003) A preliminary trophic model of Bahía de la Ascensión, Quintana Roo, Mexico. Fish Cent Res Rep 11:255-264

Submitted: June 17, 2013; Accepted: September 27, 2013 Proofs received from author(s): December 3, 2013 